\title{
Effects of Rearing Methods of Heifers during Milk Replacement Period on their Postweaning Behaviour in the Maze
}

\author{
J. BROUČEK ${ }^{1}$, M. UHRINČATั ${ }^{1}$, C. W. ARAVE ${ }^{2}$, T. H. FRIEND ${ }^{3}$, S. MIHINA ${ }^{1}$, P. KIŠAC ${ }^{1}$, A. HANUS ${ }^{1}$ \\ ${ }^{1}$ Research Institute of Animal Production, Nitra, Slovakia, ${ }^{2}$ Utah State University, Logan, UT, USA, \\ ${ }^{3}$ Texas A\&M University, College Station, TX, USA \\ Received July 12,2002 \\ Accepted November 18, 2002
}

Abstract

Brouček J., M. Uhrinčat, C. W. Arave, T. H. Friend, S. Mihina, P. Kišac, A Hanus: Effects of Rearing Methods of Heifers during Milk Replacement Period on their Postweaning Behaviour in the Maze. Acta Vet. Brno 2002, 71: 509-516.

Fifty-eight Holstein heifer calves were assigned to one out of three treatment groups after having nursed by their mothers for the first week: BN) individual hutch, bucket with nipple $n=25$; DF) loose housing pen, machine milk feeder, $n=16$; NC) loose housing pen, nursing cow, $n=17$. After weaning at 8 weeks, all calves were kept in group pens. At 15 weeks of age, the behaviour in the 6 -unit maze $(16.4 \times 4.5 \mathrm{~m})$ was determined. On the first observation day, the calves were tested five times (the first one for training); on the second day there were four runs. The calves had to solve two tasks. In task A, the passage was open on the left side, and on the right side (task B) on the next day. We were testing the following hypothesis: the speed of traversing the maze is affected by the rearing system. The slowest were NC calves. On the first day (task A), the average time to traverse the maze among treatments DF (43.9 s), BN (53 s) and NC (111.3 s) was different $\left(\mathrm{F}=8.26^{* * *}, P=0.0007\right)$. On the second day (task B), the averages were: BN $77.1 \mathrm{~s}, \mathrm{DF} 83.8 \mathrm{~s}$ and DC $166.6 \mathrm{~s}(\mathrm{~F}=8.17 * * *, P=0.0008)$. The results indicate that the feeding method and housing used to rear calves may have a significant impact on their maze behaviour.

Heifers, behaviour, maze, feeding, housing

During the period from birth to weaning, the calf is exposed to several environmental factors that can affect its behaviour in the maze. It is necessary to create an adequate environment that will ensure the welfare of animals during rearing. That means we should apply such systems of rearing which correspond to the physiological and behavioural needs of animals. This is most markedly illustrated with regard to formulas of behaviour and production efficiency of an organism (Friend 1989; B aranyiová and Holub 1993). The period of liquid feeding represents a critical period of life for calves. This period decides about their health, resistance to diseases and later efficiency. If we ignore nutrition, animals can be influenced by three main factors: manner of housing, method of liquid feeding and time of weaning from mother. The situation at the time of weaning is similar in all countries with advanced agriculture. The majority of calves are removed from mother immediately after birth and fed with milk replacer from the fourth day of life. Only about $10 \%$ of calves, particularly from small herds, are fed native milk until weaning, and so one of the basic demands on rearing calves in sustainable agriculture can be fulfilled (Krohn et al. 1999). For animals used to a social way of life, isolation poses significant psychological stress with an extensive scope of behavioural and physiological responses (Albright and Arave 1997). Early separation of the calf from the cow is popular in the dairy industry, and is deemed by some to be essential to maximum production. Others consider this practice to be against nature. It is probable that very early weaning from mother reduces adaptive abilities of calves and decreases their resistance to stress during some methods of manipulation and treatment, particularly during group mixing and transport. Stressors operating in the prenatal

Address for correspondence:

Ing. Jan Brouček, DrSc.

Ing. Jan Brouček, DrSc.
Research Institute of Animal Production

Hlohovská 2 ,

94992 Nitra, Slovakia
Phone: +421376546280

Fax: +421 376546483

http://www.vfu.cz/acta-vet/actavet.htm 
or early postnatal period can influence development, behaviour and physiological reactions of individuals (Hvozdík 1991; Weinstock 1997). It is often necessary to separate an animal from a group or to mix groups together in modern as well as traditional systems of management. These interventions cause psychological stresses.

Many authors have studied the effect of early rearing experience on behaviour. Purcell and Arave (1992) found that pre-weaning isolation affected growth, feed intake, dominance rank, and learning ability. Various ethological methods are used for an assessment of early experiences. We opted for the maze test, which is used in research on the orientation and memory of animals. Kilgour (1981) recommended the closed-field maze test as an appropriate apparatus for the testing of the learning ability of dairy cows. The authors Arave et al. (1992) tested the calves from 1st to 3rd day after weaning in a maze. The male calves were slower to find the food reward than females. The heifer-calves had learned well from their mistakes. Ninety-two Holstein heifer calves were assigned to one of five rearing treatments after having nursed their mothers for $24 \mathrm{~h}$ in the work of Brouček et al. (1999). At 15 weeks of age, the time to traverse a maze was determined. Calves reared by drinking automate appear to be the most adaptable, and calves reared by nursing cows showed worse orientation in unfamiliar space and were the least adaptable.

The aim of this experiment was to prove two hypotheses: the behaviour in maze learning ability tests is affected by the feeding method and by the housing system.

\section{Materials and Methods}

Treatments

Fifty-eight Holstein heifer calves which were randomly divided to one out of three feeding treatments and to two housing treatments after having nursed their mothers for the first week: BN) individual hutch, feeding from bucket with nipple, $n=25$; DF) a loose housing pen with milk drinking machine feeder, $n=16$; NC) a loose housing pen with nursing cows until weaning, $n=17$. The weaning was carried out for all animals at the age of 8 weeks. Animals of all treatments were kept after weaning in common group pens in a loose housing with bedding in age-balanced groups.

Feeding

All calves sucked colostrum in free choice from their mothers during the first 24 hours. From the second to the seventh day they suckled the mother's udder three times per day. All mothers were milked from the second day on after parturition. Calves of the treatment BN got after first three days, when they were made to drink milk replacer, $6 \mathrm{~kg}$ of milk replacer per day from a bucket with nipple divided into 2 portions in $12 \mathrm{~h}$ intervals. Calves of the treatment DF were drinked from the eighth day morning by a drinking automate. After the first three days, when they were made to drink milk replacer, they received $6 \mathrm{~kg}$ of milk replacer per day divided into 4 portions et $6 \mathrm{~h}$ intervals. Animals from the treatment NC were moved to a nursing cow pen on the eighth day morning. The number of calves per one nursing cow was determined according to their milk yield $(6 \mathrm{~kg}$ milk per each calf). A maximum of 3 cows were housed in one pen $8 \times 4.5 \mathrm{~m}$ in size. From the second day until weaning the calves could eat starter mixtures and alfalfa hay in free choice. They received $1.5 \mathrm{~kg}$ of concentrate mixture per day and alfalfa hay in free choice from weaning to 180 days. From the age of 90 days they got

The maze for dairy calves

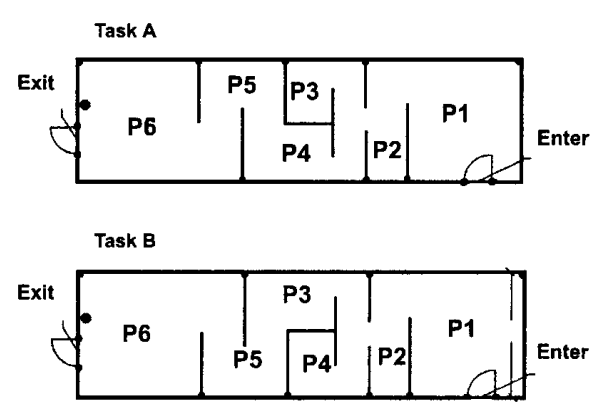

\section{Behaviour}

Behaviour was evaluated using the maze (Fig. 1). The 6 -unit maze was constructed in the pen $16.4 \times 4.5 \mathrm{~m}$ from steel fence $1.5 \mathrm{~m}$ high covered with a black plastic sheet. Five barriers were installed inside which marked the beginning and the end of the route and also particular parts of the maze. In the exit part a red bucket with feed mixture was placed. Each calf was put to the maze entrance and the door was closed behind it. If the calf stood without movement in the some part longer than 3 minutes, it was forced gently to movement. The calf was allowed to eat for only a few seconds, whereupon it was led out of the maze to repeat the procedure. If the calf stood without movement longer than 3 minutes in the rear part of the 
maze, it was taken out of the maze. Time was recorded from the moment of the entry to the first feeding or from the entry to the exit.

The calves had to solve two tasks on two consecutive days. On the first observation day (task A), the calves were tested five times, three runs in the morning and two runs in the afternoon. The first test was for training. On the second day (task B), there were two runs in the morning and two runs in the afternoon. In task A, the passage was open on the left side, and on the right side (task B) on the next day. Every entrance to the P3 part in task A or the entrance to the $\mathrm{P} 4$ part in the task B (blind way) was considered a mistake. Vocalization, defecation, urination, and exploratory behaviour were recorded by a video camera. The data were analyzed using an analysis of variance. Significant differences between means were tested by Tukey's test.

\section{Results and Discussion}

The time of standing in the maze was generally decreased on the first day (task A) in the groups $\mathrm{BN}$ and DF from the first to the fourth run, the longest standing time wassignificant in treatment group NC in the second to fourth runs. Animals from DF treatment responded differently, the time of standing rose in the second run and only in the fourth run it got under the level of the first run. The index was significantly higher in NC group from the second to fourth run in comparison with $\mathrm{BN}$ and DF treatments.

In the fifth run (second observation day), the index was significantly prolonged in all treatments after the change of the task, and the differences were not significant. The longest standing time (178 s) was again recorded in treatment NC. In the runs No 6 to 8, the animals from BN and DF groups quickly accommodated themselves to the change of the task, but the trend of long staying in the maze was maintained in treatment NC. Differences between $\mathrm{NC}$ and other treatments groups were significant also in the evaluation of particular days (Table 1). The shortest standing times in the maze during the first day were recorded in treatment DF (24 s), on the second day in BN (49 nebo $53 \mathrm{~s}$ ). On the first day (task A), the average time of standing in the maze among treatments DF (24 s), BN (34 s) and NC (88 s) was different $(\mathrm{F}=8.44 * * *)$. On the second day (task $\mathrm{B})$, the averages were: BN 53 s, DF 62 $\mathrm{s}$ and $\mathrm{DC} 138 \mathrm{~s}(\mathrm{~F}=8.22 * * *)$. In the evaluation of the average for both days, the longest time was in NC treatment (113 s), times in BN and DF were similar (43.8 s and $43 \mathrm{~s}$ ). Differences were significant $\left(\mathrm{F}=13.55^{* * *}\right)$.

Table 1

Total times of standing during individual days (s)

\begin{tabular}{|c|c|c|c|c|c|c|}
\hline Group & $\mathrm{n}$ & $\overline{\mathrm{x}}$ & SD & $\min$ & $\max$ & Significance \\
\hline \multicolumn{7}{|l|}{ 1. day } \\
\hline $\mathrm{BN}$ & 25 & 34.14 & 28.51 & 0 & 117.00 & $\mathrm{~F}=8.44^{* * * *}$ \\
\hline DF & 16 & 24.02 & 42.68 & 0 & 164.50 & $\mathrm{P}=0.0006$ \\
\hline $\mathrm{NC}$ & 17 & 88.04 & 73.93 & 3.50 & 209.50 & $\mathrm{NC}: \mathrm{BN}^{* * *}$ \\
\hline total & 58 & 47.15 & 49.41 & 0 & 209.50 & $\mathrm{NC}: \mathrm{DF}^{* * * *}$ \\
\hline \multicolumn{7}{|l|}{ 2. day } \\
\hline $\mathrm{BN}$ & 25 & 53.44 & 47.75 & 5.50 & 164.50 & $\mathrm{~F}=8.22^{* * *}$ \\
\hline DF & 16 & 61.98 & 62.76 & 0 & 253.75 & $\mathrm{P}=0.0008$ \\
\hline $\mathrm{NC}$ & 17 & 138.14 & 98.33 & 20.75 & 324.00 & $\mathrm{NC}: \mathrm{DF}^{* *}$ \\
\hline total & 58 & 80.62 & 69.87 & 0 & 324.00 & $\mathrm{NC}: \mathrm{BN}^{* * *}$ \\
\hline \multicolumn{7}{|c|}{ Average for both days } \\
\hline $\mathrm{BN}$ & 25 & 43.79 & 28.49 & 5.75 & 99.63 & $\mathrm{~F}=13.55^{* * *}$ \\
\hline DF & 16 & 43.00 & 46.72 & 0 & 169.13 & $\mathrm{P}=0.0000$ \\
\hline $\mathrm{NC}$ & 17 & 113.10 & 63.50 & 17.00 & 246.25 & $\mathrm{NC}: \mathrm{DF}, \mathrm{BN}^{* * *}$ \\
\hline total & 58 & 64.20 & 46.07 & 0 & 246.25 & \\
\hline
\end{tabular}


Table 2

Times acrossing the maze on individual days (s)

\begin{tabular}{|c|c|c|c|c|c|c|}
\hline Group & $\mathrm{n}$ & $\bar{x}$ & SD & $\min$ & $\max$ & Significance \\
\hline \multicolumn{7}{|l|}{ 1. day } \\
\hline $\mathrm{BN}$ & 25 & 53.05 & 30.16 & 11.75 & 134.00 & $\mathrm{~F}=8.26^{* * *}$ \\
\hline DF & 16 & 43.89 & 46.22 & 10.25 & 190.50 & $P=0.0007$ \\
\hline $\mathrm{NC}$ & 17 & 111.34 & 79.80 & 20.75 & 249.25 & $\mathrm{NC}: \mathrm{BN}, \mathrm{DF}^{* *}$ \\
\hline total & 58 & 67.61 & 53.22 & 10.25 & 249.25 & \\
\hline \multicolumn{7}{|l|}{ 2. day } \\
\hline $\mathrm{BN}$ & 25 & 77.07 & 50.26 & 21.00 & 194.75 & $\mathrm{~F}=8.17^{* * *}$ \\
\hline DF & 16 & 83.79 & 65.12 & 13.25 & 278.50 & $\mathrm{P}=0.0008$ \\
\hline $\mathrm{NC}$ & 17 & 166.56 & 106.75 & 39.00 & 359.75 & $\mathrm{NC}: \mathrm{DF}^{* *}$ \\
\hline total & 58 & 105.16 & 74.66 & 13.25 & 359.75 & $\mathrm{NC}: \mathrm{BN}^{* * * *}$ \\
\hline \multicolumn{7}{|c|}{ Average for both days } \\
\hline $\mathrm{BN}$ & 25 & 65.06 & 30.91 & 22.13 & 128.25 & $\mathrm{~F}=13.44^{* * *}$ \\
\hline DF & 16 & 63.85 & 48.85 & 14.83 & 191.88 & $\mathrm{P}=0.0000$ \\
\hline $\mathrm{NC}$ & 17 & 138.95 & 69.48 & 31.13 & 283.00 & $\mathrm{NC}: \mathrm{BN}, \mathrm{DF}^{* * *}$ \\
\hline total & 58 & 86.38 & 49.72 & 14.83 & 283.00 & \\
\hline
\end{tabular}

The time of running across the maze did not differ significantly in the first run; it began to be significantly different in the second run. In the second, third and fourth runs, NC heifers were statistically significantly slowest (143 s, $119 \mathrm{~s}$ and $92 \mathrm{~s})$. Treatment group DF heifers took the shortest time to run across the maze during the second and third runs ( $30 \mathrm{~s}$ and 38 $\mathrm{s})$. In the fourth run, the fastest animals were of BN treatment ( $32 \mathrm{~s}$ ). The tendency to run the slowest across the maze was kept until the end of second day (task B) in treatment NC. The time of traversing the maze was similar as the standing time in the maze, decreased from the fifth to the eighth run. In the fifth run, after changing of the maze dispozition, the times were generally prolonged. The value of the $\mathrm{F}$ test decreased to the level of $\mathrm{F}=4,88, \mathrm{P}=0,0112$ in the sixth run. The laigest differences among treatments were found in the seventh run (NC $137 \mathrm{~s}, \mathrm{BN} 41 \mathrm{~s}$ and DF $45 \mathrm{~s} ; \mathrm{F}=8.64 * * *)$.

Of the average of both observation days (Table 2), treatment DF calves were the fastest (64 s), but there was a small difference against treatment BN (65 s). On the first day, the average time of traversing the maze among treatments DF (43.9 s), BN (53 s) and NC (111.3 s) was different $\left(\mathrm{F}=8.26^{* * *}\right)$. On the second day (task $\left.\mathrm{B}\right)$, the averages were: $\mathrm{BN} 77.1 \mathrm{~s}$, DF $83.8 \mathrm{~s}$ and DC $166.6 \mathrm{~s}\left(\mathrm{~F}=8.17^{* * *}\right)$. In the evaluation of the average time in all 8 runs, animals ran across the maze in this order: $\mathrm{DF}$ (64 sec.), $\mathrm{BN}(65 \mathrm{~s}), \mathrm{NC}(139 \mathrm{~s})(\mathrm{F}=13.44 * * *)$.

Calves from group DF made the least mistakes and had the least of forced exits in task A per day (0.12 and 0.19), and group NC animals the most (0.65 and 0.82). The numbers were likewise highest in group NC in task B (3.00 and 0.82). In the average number of mistakes made in task B, animals from group DF and BN were comparable (2.19 and 2.20). The smallest number of forced exits was in groups $\mathrm{BN}(0.32)$. In the evaluation of the entire maze test, groups $\mathrm{BN}$ and DF proved the best adaptable, and calves from group $\mathrm{NC}$ the worst adaptable.

As far as breeding of dairy cows is concerned, there are discussions about the most suitable rearing system for heifers to give them welfare and good quality rearing which influence their subsequent efficiency (Strapak and Aumann 1998). The effect of early experience (Friend and Dellmeier 1988) is also a generally accepted factor. It is also important that reared heifers are resistant to stress and able to adapt to altered conditions of environment in coherence with new procedures and methods of dairy cows management 
(automated feeding, robotization of milking). It was our aim to incorporate into the experiment the maximum number of rearing alternatives with separation of calves from their mothers at the same age, with different ways of feeding and various possibilities of movement.

The results of behavioural tests indicated unambiguously that heifer calves after weaning, at the age 15 weeks, can be very susceptible to stress situations. If they are moved to another housing during this period, which brings along many new, for the animal strange situations, it is necessary to take into account that there will be a negative impact on their behaviour and growth intensity (Veissier et al. 1994). The precondition of quick orientation is the prompt reaction of the nervous system (Munksgaard and Jensen 1996). However, it must not overcome a certain limit because it could lead to excitement. The animals of NC treatment group showed the worst orientation in maze in our experiment. Animals reared with mother or foster mother for a longer period are not independent and are unable to adapt quickly.

The best learning was in calves DF, which drank by computer controlled feeder. But there was a small different between this treatment and BN calves. These both groups were smart, independent and disciplined. Similar results in the comparison of the behaviour of calves were found by Brouček et al. (1999). Calves reared by nursing cows were lacking independence and showed worse orientation. Differences in the maze behaviour between housing treatment groups were not so expressive as among feeding treatment groups. Purcell and Arave (1991) found out that calves reared in individual hutches reached the goal in a T maze significantly sooner than calves reared in groups. This is an interesting finding, because in the above-mentioned experiment with five groups of calves (B rouček et al. 1999), we ascribed the faster learning of calves from loose housing to automated feeding. According to Kiley-Worthington and Savage (1978), farm animals learn constantly about their environment, feeding schedules, and the movements required of them. Calves from this group had to get used to 6-h drinking intervals and to a disciplined line-up position in front of the drinking box (Brouček et al. 1992). Many references say that early weaning from mother decreases the ability of animals to adapt to a new environment later (Napolitano et al. 1995). If we consider separation from mother in the seventh day early, we should obtain opposite results.

The animals kept in loose housing with nursing cows until weaning had the worst orientation in the maze. It is very difficult to explain this phenomenon. There is a lack of sources, nobody has probably dealt with this problem except for us. There has been generally little research into the effect of rearing on maze behaviour of calves, only heifers weaned from mothers during first $24 \mathrm{~h}$ of life were observed (Arave et al. 1992; Purcell and Arave 1991). There is a lack of information about animals reared by own or adopted mothers until weaning from liquid nutrition.

If we can use sources on social behaviour, we mentioned results of Neindre and Sourd (1984), who found that Holstein heifers reared by foster mothers were more active in group and more dominant than heifers reared in individual housing with bucket drinking. These showed anxious reactions during the process of separating. This could be one of the reasons for slowlier learning of those animals. The animal is alone in the maze and must decide independently. Fear worsens learning in the maze. Fearful animals are significantly slower in instrumental and also in spacial learning (Wolff and Hausberger 1996). We must not forget that individual location of animal in an unknown environment can evoke fear, exploring and social motivations (Friend and Dellmeier 1988; Veissier and Neindre 1992; Passille and Rushen 1997). According to Jones (1997), fearful manifestations are a part of the temperament of each animal. The level of fearful reactions develops especially in juvenile life on the basis of interaction between genetic fond and factors of 
environment (B o is s y 1995). It was also found that handling during ontogenesis and before testing accelerates learning (Heird et al. 1983). Hart (1985) describes an experiment in which animals were exposed to negative (electric shock) and positive handling. In later tests for emotionality, both the handled and the shocked animals moved about more freely, defecated and urinated less frequently, and showed fewer signs of emotional activation than the control group of non-manipulated animals. The virtue of handling is changing with age; handling before weaning generally decreases later emotionality, while the handling after weaning has only a low significance (Ma s on 2000).

How to account for differences in behaviour between treatments DF and BN on the one hand and $\mathrm{NC}$ on the other? We have three hypotheses: handling, fear and time of weaning from mother. Besides, it seems that animals kept for a long time only with their own mother or a foster cow are independent (perhaps it is not antropomorphism) and they are not able to quickly adapt. It was proved also in our previous experiment focused on maze behaviour of heifers and bulls (B rouček et al. 2002). However, the term lack of independence is closely connected with fear and we can come again to the effect of handling on the decrease in emotionality (Hart 1985). As was proved in the evaluation of behaviour of heifers from various rearing systems in open-field tests (Brouček et al. 2000), the animals raised by foster cows had the worst relationship to unfamiliar humans and showed the least explorating and playing activities in comparison to animals from other rearing systems. According to Vessier et al. (1998), this can be caused also by the effect of weaning from foster mother. It may came to a violent interruption of the close mother-young bond. This bond was highlighted by the time of duration (seven weeks). In our opinion, the worse orientation and slower learning in the maze of heifers reared by nursing cows is caused by the lack of handling, which had a significant impact only in the group from individual hutches (BN), and an impossibility of instrumental learning, which was the most expressively pronounced in the group from the drinking feeder (DF).

\section{Conclusions}

Technological systems with loose housing are good for animals that learn well, ase adaptable, tolerant and have good orientation skills. They must be able to quickly adapt to a change of environment. It was found in the experiment in which we were comparing the maze behaviour of weaned heifers that the worst orientation was in the group from nursing cows. According to the time of traversing the maze, assessment of the number of mistakes and forced exits from the device, the heifers fed by a drinking feeder controlled by computer and by a bucket with nipple were well adaptable. Calves reared by suckling cows showed a worse orientation in unfamiliar space and were the least adaptable. There were no significant differences between the behaviour of heifers reared in loose housing with a drinking feeder and heifers from individual hutches with drinking through a sucking nipple from the bucket. The results indicate that the feeding and housing method as used to rear calves may have a significant impact on their maze behaviour.

\section{Vliv metody odchovu jalovic během mléčné výživy na jejich chování v bludišti po odstavu}

58 jalovic holštýnského plemene bylo po týdnu stráveném sáním svých matek rozdělených do třech skupin: $\mathrm{BN}$ ) individuální bouda, vědro s cumlem, $\mathrm{n}=25 ; \mathrm{DF}$ ) volné ustájení, napájecí automat, $\mathrm{n}=16$; NC) volné ustájení, kojné krávy, $\mathrm{n}=17$. Po odstavu ve věku 8 týdnů byla telata chována ve skupinových kotcích. Ve věku 15 týdnů se zkoumalo chování v bludišti, skládajícího se ze šesti částí $(16.4 \times 4.5 \mathrm{~m})$. Telata řešila dvě otázky. V otázce A byla cesta otevřená na levou stranu a druhý den (otázka B) na pravou. Testovali 
jsme hypotézu: rychlost přechodu bludištěm je ovlivněna metodou krmení a ustájením. Nejpomalejší byla telata skupiny NC. První den (otázka A) byly průměrné časy přechodu bludištěm statisticky průkazně rozdílné: $\mathrm{DF}(43.9 \mathrm{~s}), \mathrm{BN}(53 \mathrm{~s})$ a NC $(111.3 \mathrm{~s})\left(\mathrm{F}=8.26^{* * *}\right.$, $\mathrm{P}=0.0007$ ). Druhý den (otázka $\mathrm{B}$ ), byly průměry následovní: $\mathrm{BN} 77.1 \mathrm{~s}, \mathrm{DF} 83.8 \mathrm{~s}$ a NC $166.6 \mathrm{~s}(\mathrm{~F}=8.17 * * *, \mathrm{p}=0.0008)$. Výsledky naznačují, že metoda krmení mléka a ustájení během odchovu telat má průkazný dopad na jejich bludištové chování.

\section{References}

ALBRIGHT, JL, ARAVE, CW 1997: The Behaviour of Cattle. CAB International, 299 p.

ARAVE, CW, LAMB, RC, ARAMBEL, MJ, PURCELL, D, WALTERS, JL 1992: Behaviour and maze learning ability of dairy calves as influenced by housing, sex and sire. Appl Anim Behav Sci 33: 149-163

BARANYIOVA, E, HOLUB, A 1993: The effects of diarrhoea on food intake in piglets weaned on the day of birth. Vet Med (Praha) 38: 659-665

BOISSY, A 1995: Fear and fearfulness in animals. The Quarterly Review of Biology 70: 165-191

BROUČEK, J, MIHINA, S, JANCI, P, KOVALČIIK, K 1992: Calf behaviour in a computer-controlled management system. Sci agric bohemoslov 24: 153-160

BROUČEK, J, UHRINČAT̃, M, FRIEND, TH, ARAVE, CW, HANUS, A, MARENČÁK, S 1999: Effect of different rearing during the milking period on growth and maze behaviour of dairy calves. J Dairy Sci 82, Suppl 1, p. 77.

BROUČEK, J, UHRINČAŤ, M, FRIEND, TH, ARAVE, CW, MIHINA, S, HANUS, A, MARENČÁK, S, KIŠAC, P 2000: Effects of rearing methods of calves prior to weaning on subsequent open-field behaviour at 28 weeks of age. J Anim Sci 78, Suppl 1/J Dairy Sci 83, Suppl 1, p. 35.

BROUČEK, J, UHRINČATT, M, SANDOR, A, ARAVE, CW, MIHINA, S, WAIBLINGER, S, HANUS, A, KISAC, P 2002: Einfluss eines niedrigen Magnetfeldes auf Kälber während der pränatalen Entwicklung. Tierärztl Umschau 57: 241-248

FRIEND, TH, DELLMEIER, G 1988: Common practices and problems related to artificially rearing calves: an ethological analysis. Appl Anim Behav Sci 20: 47-62

FRIEND, TH 1989: Recognizing behavioural needs. Appl Anim Behav Sci 22: 151-158

HART, BL 1985: Early experience and behaviour. In: The behaviour of domestic animals. W.H.Freeman and Co., New York, 1985, pp. 242-262

HEIRD, JC, LENNON, AM, BELL, RW 1983: Effects of early experience on the learning ability of yearling horses. J Anim Sci 53: 1204-1209

HVOZDIK, A 1991: Ethology of risks caused by weaning in pigs. Vet med 36: 533-538

JONES, RB 1997: Fear and distress. In: APPLEBY, MC and HUGHES, BO (1997): Animal welfare. CAB International, 198 Madison Ave., New York, NY 100016, USA, pp. 75-87.

KILEY-WORTHINGTON, M, SAVAGE, P 1978: Learning in dairy cattle using a device for economical management of behaviour. Appl Anim Behav Sci 4: 119-124

KILGOUR, R 1981: Use of the Hebb-Williams closed-field test to study the learning ability of jersey cows. Anim Behav 29: 850-860

KROHN, CC, FOLDAGER, J, MOGENSEN, L 1999: Long-term effect of colostrum feeding methods on behaviour in female dairy calves. Acta Agric Scand Sect A, Anim Sci 49: 57-64

MASON, WA. 2000: Early developmental influences of experience on behaviour, temperament, and stress. In: G.P. MOBERG and J.A. MENCH (Eds.), The Biology of Animal Stress. Basic Principles and Implications for Animal Welfare. CAB International Publishing, New York, pp. 269-290.

MUNKSGAARD, L, JENSEN, MB. 1996: The use of „open field“ " tests in the assessment of welfare of cattle. Acta Agric Scand Sect. A, Anim Sci 27: 82-85

NAPOLITANO, F, MARINO, V, DE ROSA, G, CAPPARELLI, R, BORDI, A 1995: Influence of artificial rearing on behavioural and immune response of lambs. Appl Anim Behav Sci 45: 245-253

NEINDRE LE, P, SOURD, CH 1984: Influence of rearing conditions on subsequent social behaviour of Friesian and Salers heifers from birth to six months of age. Appl Anim Behav Sci 12: 43-52

PASSILLE, AM, RUSHEN, J 1997: Effect of spatial restriction on open-field activity, growth and adrenocortical activity of calves. J Dairy Sci 80: 969-974

PURCELL, D, ARAVE, CW 1991: Isolation vs. group rearing in monozygous twin heifer calves. Appl Anim Behav Sci 31: 147-156

STRAPAK, P, AUMANN, J 1998: Relations between the body conformation and commercial traits of cattle. Czech J Anim Sci 43: 293-298

VEISSIER, I, LE NEINDRE, P 1992: Reactivity of Aubrac heifers exposed to a novel environment alone or in groups of four. Appl Anim Behav Sci 33: 11-15

VEISSIER, I, GESMIER, V, LE NEINDRE, P 1994: The effects of rearing in individual crates on subsequent social behaviour of veal calves. Appl Anim Behav Sci 41: 199-210 
VEISSIER, I, BOISSY, A, NOWAK, R, ORGEUR, P, POINDRON, P 1998: Ontogeny of social awareness in domestic herbivores. Appl Anim Behav Sci 57: 233-245

WEINSTOCK, M 1997: Does prenatal stress impair coping and regulation of hypothalamic-pituitary-adrenal axis? Neurosci Biobehav Rev 21: 1-10

WOLFF, A, HAUSBERGER, M 1996: Learning and memorisation of two different tasks in horses: the effects of age, sex and sire. Appl Anim Behav Sci 46: 137-143 